\title{
Risk communication strategies: state of the art and effectiveness in the context of cancer genetic services
}

\author{
Claire Julian-Reynier*,1, Myriam Welkenhuysen ${ }^{2}$, Lea Hagoel ${ }^{3}$, Marleen Decruyenaere ${ }^{2}$ and \\ Penelope Hopwood ${ }^{4}$ on behalf of the CRISCOM Working Group ${ }^{5}$
}

\begin{abstract}
${ }^{1}$ INSERM U379, Epidemiology and Social Sciences Applied to Medical Innovation, Institut Paoli-Calmettes, Marseille, France; ${ }^{2}$ Centre for Human Genetics, Leuven, Belgium; ${ }^{3}$ Technion Institute, Haifa, Israel; ${ }^{4}$ Christie Hospital, Manchester, UK
\end{abstract}

The objective of this paper is first to describe the different strategies used to communicate risks to patients in the field of cancer or genetics, to review their effectiveness, and to summarise the state of the art of this practice in particular, in cancer genetics. The target audience is health care professionals involved in the communication of cancer risks, and genetic risks of breast/ovarian or colorectal cancer in particular. The methods include a review of the literature (Medline, Pascal, Psyclnfo, Embase) by a panel of researchers and clinicians (cancer geneticists, epidemiologists, health psychologists, sociologists) in the context of a European Project on risk communication. We highlight practices that have been shown to be effective in the context of health psychology research and those being still under consideration for use in routine practice. In conclusion, this paper adds clinical relevance to the research evidence. We propose specific steps that could be integrated in standard clinical practice based on current evidence for their usefulness/ effectiveness.

European Journal of Human Genetics (2003) 11, 725-736. doi:10.1038/sj.ejhg.5201037

Keywords: BRCA1; BRCA2; cancer; communication; HNPCC; risk

\section{Introduction}

Cancer genetic consultations represent a recent development, but remain oriented in traditional genetics in terms of information-giving and counselling. ${ }^{1}$ Reasons given for the assessment and communication of breast/ovarian cancer risks include: to guide decisions about the use of

*Correspondence: Dr C Julian-Reynier, INSERM U379, Paoli-Calmettes Institute, 232 Bd Sainte Marguerite, 13009 Marseille, France; Tel: + 33 491223 502; Fax: + 33491223 504; E-mail: julian@marseille.inserm.fr

${ }^{5}$ Members of the CRISCOM Working Group are: Belgium, M Decruyenaere, G Evers-Kiebooms, E Legius, M Welkenhuysen (Centre for Human Genetics of Leuven); Israel, L Hagoel, G Rennert (Technion Institute, Haïfa); Italy, G De Palo, C Borreani, L Gangeri (Instituto Nazionale di Tumori, Milano); France, P Bourret, F Chabal, C Julian-Reynier, JP Moatti, C Sevilla (INSERMU379, Marseille), F Eisinger, H Sobol (Institut PaoliCalmettes, Marseille); Germany, I Nippert (Medizinische Fakultät der Westfälischen Wilhelms-Universität, Münster), B Schlegelberger (Medizinische Hochschule Hannover); Netherlands, A Tibben, C Van Asperen (Department of Clinical Genetics, Leiden University Medical Center), UK, G Evans, P Hopwood (Christie Hospital, Manchester). mammography in young women, use of Tamoxifen chemoprevention of breast cancer and to help decisions about hormone replacement therapy, and prophylactic surgery, either preventative mastectomy or oophorectomy. For colorectal cancers, the purpose is to organise surveillance by colonoscopy or to decide about preventative colectomy. ${ }^{2,3}$ We will focus here on the information-giving part of the process and in particular on the communication of risks.

The objective of this discussion paper is first to describe the different strategies used to communicate risks to patients, in particular, in the field of cancer genetics and to summarise what is known about their respective effectiveness. We highlight the approaches that have been shown to be effective in the context of health psychology research, and those being still considered for their transfer in routine practice. The review will be of interest to health care professionals involved in the communication of cancer risks, genetic risks of breast/ovarian or colorectal 
cancer in particular. We conclude with suggested steps in risk communication that could be integrated in standard practice, based on evidence of their utility and/or effectiveness from empirical research.

The field of risk communication in health has been the focus of thousands of publications in the scientific literature. This paper draws on the most recent literature reviews, some of them very extensive and on recent original articles published after the reviews. Four databases (Medline, Pascal, PsycInfo, Embase) were investigated using the words 'risk, communication, cancer, genetics'. The original articles were selected on the topic of risk communication strategies in cancer and cancer genetics and on their respective effectiveness. Other key articles were considered through their citations in the reviews and through the exchange of information among the authors. A summary of the main review articles on risk communication used in the analysis is presented in Table 1 . The original articles published recently are detailed in Table 2 since the others were included in the reviews cited in Table 1.

\section{Definitions of risk communication and risk perception}

Risk communication can be defined as an 'Interactive process of exchange of information and opinion among individuals, groups and institutions. It involves multiple messages about the nature of risks or about the legal and institutional arrangements for risk management ' (National Research Council cited by Rimer and Glasman). ${ }^{4}$ This definition moves away from the notion that information is communicated from provider to patient and that acceptability (or not) of the risk is communicated back. ${ }^{5}$ The traditional definition of risk as the probability of a negatively valued event' can be extended as a multidisciplinary concept by including elements such as its magnitude, the seriousness of the possible loss and the variance of all possible negative consequences of the event considered. ${ }^{6}$

Risk perception may be considered as an intermediate variable studied in association with risk-reducing behaviour or as an outcome of risk communication; it is also a key determinant of health behaviour models. ${ }^{7}$ Perception of risk is a multifaceted concept, comprising the potential degree of harm of the event (in this case, cancer), on its controllability, on the number of people simultaneously exposed, on the familiarity of consequences and effects and on the degree of subjective control over the risk. ${ }^{6}$ Risk perception is also dependent on the individual's defensive responses to health communication. Heightening risk perception without adequately addressing specific methods or improving self-efficacy for risk reduction may increase distress and induce behavioural inaction. ${ }^{6,8}$

\section{Objectives of risk communication in cancer genetics}

At its simplest level, the primary purpose of risk communication is simply to provide information to individuals with a particular personal/family cancer history, so that they know whether they actually have an increased risk of cancer. There are also two main medical objectives for risk ascertainment and communication. The first is the need to change or modify behaviour, often using change in risk perception, as a 'proxy' variable in empirical studies. In the context of cancer genetic communication, this objective can be assessed as behaviours such as genetic test uptake, diffusion of information in the family, preventive behaviours and screening by colonoscopy or mammography, for example. More recently, risk communication has been considered to enable people to make informed decisions and to help them better decide which risks they should accept and which they should avoid or reduce. ${ }^{9-11}$ This second medical objective would focus on outcomes such as the facilitation of 'informed decision-making' for genetic test uptake and/or for different preventive interventions.

\section{Characteristics of risk communication in cancer genetics}

The assessment of cancer risk is based on knowledge of the average risk of cancer for the general population, considered as the reference estimate to which the impact of risk factors will be compared. Among the risk factors studied, the family history and its correlate, the genetic risk, have the highest impact on the onset of breast/ ovarian/colorectal cancers. In the mid-1990s, two major genes (BRCA1 and BRCA2) were identified for genetic susceptibility to breast/ovarian cancer, although it is thought that other genes also play a role in the onset of these diseases. ${ }^{12}$ Among the genes identified for non polyposis colorectal cancer, the three most prevalent genes studied in clinical practice are MLH1, MSH2 and MSH6. ${ }^{3}$ Genetic testing when it is possible to identify a deleterious mutation in a family gives essential information for all the relatives, even if it is recognised that these genes only represent a small part of the complexity. 3,13

Information about genetic cancer risk is more complex than risk information concerning classical Mendelian diseases, because genetic cancer risk information concerns multiple risks and because uncertainty is associated with most risk estimators. The following points summarise this complexity.

From the multiple risks and probabilities discussed during the communication process, we can distinguish:

- all the relevant cancer risk factors (including epidemiological and personal factors) and in particular family cancer history;

- the probability of having a cancer predisposing gene running in the family; 
Table 1 Characteristics of the main review articles considered

\begin{tabular}{|c|c|c|c|c|}
\hline Reference No. & Goal of the study & Methods & Focus and outcome considered & Results/conclusion \\
\hline 26 & Synthesis and discussion paper & $\begin{array}{l}\bullet 75 \text { published papers } \\
\text { analysed } \\
\bullet \text { Qualitative analysis }\end{array}$ & $\begin{array}{l}\text { Communication of risks in the context } \\
\text { of familial cancer }\end{array}$ & $\begin{array}{l}\text { Definitions of main concepts Highlights the } \\
\text { challenges of uncertainties in } \\
\text { communicating familial cancer risks }\end{array}$ \\
\hline 60 & Synthesis and review & $\begin{array}{l}\bullet 72 \text { cited references } \\
\bullet \text { Qualitative analysis }\end{array}$ & $\begin{array}{l}\text { Communication of individual cancer } \\
\text { risks, of risks inherent to genetic } \\
\text { testing, family communication of risks }\end{array}$ & $\begin{array}{l}\text { Highlights the constant overestimation of } \\
\text { breast cancer risks, the absence of influence } \\
\text { of education on risk perception and the role } \\
\text { of individual and family coping processes on } \\
\text { risk information and decision-making }\end{array}$ \\
\hline
\end{tabular}

-46 cited references

-Qualitative analysis

-45 cited references

-Qualitative analysis

-116 cited references

-Qualitative analysis

- 90 cited references

-Qualitative analysis

-94 cited references

-Qualitative analysis 21 published or in press studie in randomised controlled trials qualitative analysis
Communication process between a transmitter and a receiver

- Not focused on cancer

Relation between risk perception and precautionary behaviour

\section{Specificity of the communication} addressing multiple risks

Focus on the improvement of risk communication through visual displays (risk ladders, stick and facial figures, line graphs, dots, pie charts, histograms)

-Not focused on cancer

Efficacy of decision aids for options affecting cancer outcomes

Effectiveness of TPC ${ }^{a}$ on health behaviours (diet, smoking, mammography, hormonal replacement), and on health risk appraisal, genetic susceptibility to cancer in particular
Discusses the need for the transmitter to select the kind of risk information that should be communicated qualitatively and quantitatively

Highlights the interest of the process of tailoring risk communications to individual characteristics of targets to influence behaviour (role of feedback in particular)

Highlights the need to compare different risks and to prioritise between multiple risks

- Most of the evidence suggests that combining visuals with numerical and written information affects outcomes such as the helpfulness of the information, perceived risk and trust

- Few experimental research in the field of communicating cancer risks

- Nontheoretical research

- Gives guidelines for maximising the

effectiveness of graphs and specific

problems related to small probability events and to the audience

Decision aids reduce some dimensions of decisional conflict

They increase the likelihood that choices are based on better knowledge, on realistic expectations of outcomes and on personal values

TPC ${ }^{a}$ increase:

- awareness about risks and benefits - accuracy about risk estimation more positive that null events were observed with TPC

- limits: heterogeneity (TPC and topics surveyed) 
Table 1 (Continued)

\begin{tabular}{|c|c|c|c|c|}
\hline Reference No. & Goal of the study & Methods & Focus and outcome considered & Results/conclusion \\
\hline 20 & Review and discussion paper & $\begin{array}{l}\bullet 77 \text { cited references } \\
\bullet \text { Qualitative analysis }\end{array}$ & $\begin{array}{l}\text { Impact of health risk information } \\
\text { (numeral or contextual) on different } \\
\text { outcomes/knowledge, beliefs, } \\
\text { perceptions, intentions }\end{array}$ & $\begin{array}{l}\text {-The authors believe that an intervention } \\
\text { helping people to understand how a health } \\
\text { problem could develop (antecedents) and } \\
\text { recognise what could happen to them } \\
\text { (consequences) offers the most effective } \\
\text { way to communicate risk information } \\
\text {-Tempered by the absence of studies that } \\
\text { have systematically compared the merits of } \\
\text { different intervention approaches }\end{array}$ \\
\hline 43 & Review & $\begin{array}{l}82 \text { papers included in regression } \\
\text { analysis }\end{array}$ & $\begin{array}{l}\text { Effectiveness of one to one risk- } \\
\text { communication interventions in } \\
\text { health care/behaviour change/ } \\
\text { knowledge/anxiety/risk perception }\end{array}$ & $\begin{array}{l}\text { Risk communication interventions may be } \\
\text { most productive if they include individual } \\
\text { risk estimates in the discussion between } \\
\text { professional and patient }\end{array}$ \\
\hline 52 & Discussion and review & $\begin{array}{l}\text {-41cited references } \\
\text { - Qualitative analysis }\end{array}$ & $\begin{array}{l}\text { - Association between genetic risk } \\
\text { information and behavioural change } \\
\text { - Not focused on cancer }\end{array}$ & $\begin{array}{l}\text { - Based on theories of behavioural change } \\
\text { - Preliminary evidence does not show an } \\
\text { increase of motivation to comply with } \\
\text { medical recommendations when risk is of } \\
\text { genetic origin }\end{array}$ \\
\hline 5 & Clinical review & $\begin{array}{l}\text { - } 30 \text { cited references } \\
\text {-Qualitative analysis }\end{array}$ & $\begin{array}{l}\text { Shared decision-making for } \\
\text { communicating cancer risks }\end{array}$ & $\begin{array}{l}\text { Discusses: } \\
\text { • Risk presentation formats and guidelines } \\
\text { for simplification } \\
\text { • Framing effects } \\
\text { • Highlights the interest of tailored } \\
\text { information and decision aids }\end{array}$ \\
\hline 57 & Review & $\begin{array}{l}12 \text { studies included in } \\
\text { quantitative meta-analysis }\end{array}$ & $\begin{array}{l}\text { Impact of cancer genetic counselling } \\
\text { in women at risk of developing } \\
\text { hereditary breast cancer on risk } \\
\text { perception and anxiety }\end{array}$ & $\begin{array}{l}\text { Genetic counselling is effective: } \\
\text { - In decreasing anxiety } \\
\bullet \text { In improving the accuracy of perceived } \\
\text { risk }\end{array}$ \\
\hline
\end{tabular}


Table 2 Characteristics of the original studies reviewed

\begin{tabular}{|c|c|c|c|c|}
\hline Reference & Goal of the study & Methods & Outcomes measured & Result \\
\hline 38 & Descriptive & $\begin{array}{l}\text { Qualitative } \\
\text { Telephone interviews } \\
\text { Tape recording consultations } \\
\text { Postal questionnaires } \\
\text { Face to face interviews } \\
\text { Women attending a cancer } \\
\text { family clinic } N=46 \\
\text { Average age } 40\end{array}$ & $\begin{array}{l}\text { - Real risk presentation during } \\
\text { counseling } \\
\text { • Patients' preferences for risk } \\
\text { formats }\end{array}$ & $\begin{array}{l}\text { - } 73 \% \text { preferred the risk to be presented in } \\
\text { quantitative formats (little difference for } \\
\text { percentages, proportions or population } \\
\text { comparisons) } \\
\text { - In } 40 \% \text {, the risk was not presented in the } \\
\text { preferred format }\end{array}$ \\
\hline 53 & Descriptive & $\begin{array}{l}\text { Qualitative } \\
\text { Nine cognitive interviews } \\
\text { Nine focus groups }(N=42) \\
\text { General population (volunteers) } \\
\text { • } 70 \% \text { female } \\
\text { Average age } 50\end{array}$ & $\begin{array}{l}\text { - Evaluation of wording and } \\
\text { presentation of the Harvard Cancer } \\
\text { Risk Index (HCRI) } \\
\text { - Impact of HCRI on risk perception } \\
\text { and intention to modify risk factors }\end{array}$ & $\begin{array}{l}\text { - Well received by the participants } \\
\text { - Could motivate anxiety for nonmodifiable } \\
\text { risks (ethnicity or family risks) } \\
\text { - Motivate intentions to change behaviour } \\
\text { towards risk factor exposure }\end{array}$ \\
\hline 21 & $\begin{array}{l}\text { Evaluative } \\
\text { (absolute vs } \\
\text { relative risks vs } \\
\text { risk factors) }\end{array}$ & $\begin{array}{l}\text { Quantitative } \\
\text { RCT }^{\mathrm{a}} \\
N=122 \\
\text { Four groups informed about } \\
\text { absolute lifetime risks of } C R C^{\mathrm{b}} \\
\text { and then: } \\
1: \text { was informed about relative } \\
\text { risks of other cancers } \\
2: \text { was not informed about } \\
\text { relative risks of other cancers } \\
3: \text { was informed about other } \\
\text { risk factors (age, polyps) of CRC } \\
4: \text { was not informed about other } \\
\text { risk factors (age, polyps) of CRC }{ }^{\mathrm{b}} \\
70 \% \text { female general population } \\
\text { volunteers }\end{array}$ & $\begin{array}{l}\text { Testing the effect of different } \\
\text { formats for communicating } \\
\text { colorectal cancer risks on: } \\
\text { - Perception of absolute risks } \\
\text { - Perception of relative risks } \\
\text { intentions to get screened } \\
\text { - Worry, anxiety }\end{array}$ & $\begin{array}{l}\text { - Perception of absolute risks was increased } \\
\text { for the groups who received information on } \\
\text { risk factors } \\
\text { - Worry/anxiety, screening intentions, not } \\
\text { modified differently according to groups } \\
\text { - Screening intentions increased for all } \\
\text { groups }\end{array}$ \\
\hline 61 & Evaluative & $\begin{array}{l}\text { Quantitative } \\
\mathrm{RCT}^{\mathrm{a}} \\
\mathrm{N}=144 \\
\text { Smokers } \\
2 \times 2 \text { factorial design for } \\
\text { communicating lung cancer } \\
\text { susceptibility: } \\
\text { 1. feedback by telephone } \\
\text { 2. feedback in person } \\
\text { 3. carbon monoxide feedback } \\
\text { 4. no carbon monoxide feedback }\end{array}$ & $\begin{array}{l}\text { Testing the effect of different } \\
\text { formats for communicating lung } \\
\text { cancer susceptibility risk on risk } \\
\text { perception and frightening for } \\
\text { lung cancer }\end{array}$ & $\begin{array}{l}\text { Neither method increased smokers' } \\
\text { perceived risks for lung cancer } \\
\text { Less frightening was observed for those } \\
\text { counselled in person }\end{array}$ \\
\hline 41 & Evaluative & $\begin{array}{l}\text { Quantitative } \\
\mathrm{RCT}^{\mathrm{a}} \\
\mathrm{N}=220 \\
\text { Pregnant women } \\
\text { Numerical probability vs verbal } \\
\text { probability of residual risk for } \\
\text { Down's syndrome }\end{array}$ & $\begin{array}{l}\text { To compare the effects of numbers } \\
\text { vs verbal formats on perception of } \\
\text { residual risk for Down's syndrome } \\
\text { and on anxiety }\end{array}$ & $\begin{array}{l}\text { Numbers had a small beneficial effect of } \\
\text { increasing awareness of residual risks } \\
\text { without increasing anxiety } \\
\text { There was an interaction between the level } \\
\text { of education and the awareness of risks }\end{array}$ \\
\hline
\end{tabular}


Table 2 (Continued)

\begin{tabular}{|c|c|c|c|c|}
\hline Reference & Goal of the study & Methods & Outcomes measured & Result \\
\hline 34 & Descriptive & $\begin{array}{l}\text { Qualitative } \\
N=29 \\
\text { General population (volunteers) } \\
\bullet \text { Had a } 1 \text { st degree relative with breast } \\
\text { cancer } \\
\bullet \text { All female } \\
\bullet \text { Average age } 40\end{array}$ & $\begin{array}{l}\text { - Preferences for computer } \\
\text { program for genetic counsellor } \\
\text { (GC) }\end{array}$ & $\begin{array}{l}\text { GC preferred for: } \\
\text { - Addressing concerns } \\
\text { - Discussing options } \\
\text { - Making decisions } \\
\text { - Understanding, helping, interactions } \\
\text { Computer preferred for: } \\
\text { - Learning at own pace } \\
\text { - Privacy } \\
\text { - Information }\end{array}$ \\
\hline 35 & Evaluative & $\begin{array}{l}\text { Quantitative } \\
\mathrm{RCT}^{\mathrm{a}} \\
\mathrm{N}=72 \\
\text { Same population as reference Green } \\
\text { et } a l^{\beta^{4}} \\
\text { Three Block randomisation: } \\
\text { genetic counsellor (GC) alone, } \\
\text { interactive computer+GC, } \\
\text { controls }\end{array}$ & $\begin{array}{l}\text { Effectiveness of a computer } \\
\text { program to educate patients } \\
\text { about breast cancer susceptibility } \\
\text { (knowledge and intentions to } \\
\text { have testing) }\end{array}$ & $\begin{array}{l}\text { GC and computer+GC: } \\
\text { - Increased knowledge } \\
\text { - Decreased the intentions to undergo } \\
\text { genetic testing }\end{array}$ \\
\hline 47 & Evaluative & $\begin{array}{l}\text { Quantitative } \\
\text { RCT }^{\mathrm{a}} \\
N=539 \\
2 \times 3 \text { factorial design } \\
\text { (statistical frame X behaviour frame) } \\
\text { Women } \\
\text { Age } 30-70 \text { (average } 46 \text { ) } \\
\text { Random sample of telephone numbers } \\
\text { Response rate } 17 \%\end{array}$ & $\begin{array}{l}\text {-Effect of message framing on } \\
\text { breast cancer-related beliefs and } \\
\text { on behaviours }\end{array}$ & $\begin{array}{l}\text { A loss framed message led to an increase in } \\
\text { intentions to perform breast self- } \\
\text { examination }\end{array}$ \\
\hline 39 & Descriptive & $\begin{array}{l}\text { Quantitative and qualitative } \\
N=193 \\
\text { Women } \\
\text { Self-reported questionnaires } \\
\text { before and after cancer family } \\
\text { consultation, audiotapes of consultation }\end{array}$ & $\begin{array}{l}\text { Describes: } \\
\text {-The process of risk communication } \\
\text {-Women's preferences for risk } \\
\text { formats } \\
\text {-The association between risk } \\
\text { communication and risk perception }\end{array}$ & $\begin{array}{l}\text {-Preferences for numbers alone in } 50 \% \text { of } \\
\text { unaffected women (percentages preferred } \\
\text { more frequently) } \\
\text { •Preferences for lifetime risks ( } 33 \% \text { ) or next } \\
10 \text { years risks ( } 33 \% \text { ) } \\
\text { No association between risk recall or } \\
\text { satisfaction and communication formats }\end{array}$ \\
\hline
\end{tabular}

${ }^{\mathrm{a} C T}$, randomised controlled trial; ${ }^{\mathrm{b}} \mathrm{CRC}$, colorectal cancer; ${ }^{\mathrm{C}} \mathrm{BC}$ breast cancer. 
- the probability of identifying a genetic mutation in the family and in the individual (BRCA1, BRCA2, MLH1, MSH2, etc.);

- the risk of inheriting a genetic mutation from one's own parents and the risk of transmitting the mutated gene to one's own offspring, that is, the 'reproductive' risk;

- the risk of developing cancer needs to be addressed not only when a genetic mutation is present but also when such a gene is absent because of the high frequency of sporadic cancers in our populations. Furthermore, recurrent cancers of the same organ occur more frequently for hereditary cancers, and they also more frequently affect a set of organs compared to sporadic cancer. $^{14-16}$

- finally the risks attached to the prognosis of cancer and to preventative/early detection interventions (chemoprevention, surgery or surveillance) may also be discussed during the genetics consultation.

- it has to be stressed that most of the above-mentioned risks are relevant not only for the counsellee involved in the risk communication process, but also for his/her relatives. This is another typical characteristic of the genetic cancer risk.

\section{Uncertainty}

The risks presented during the cancer genetic counselling process are also characterised by an uncertainty around most of the estimators, in particular for the penetrance of the genes. The estimates of the penetrance values of the BRCA genes appear to vary, from 60 to $85 \%$ for breast cancer and between 15 and $40 \%$ for ovarian cancer. ${ }^{2,17,18}$ For the hereditary nonpolyposis colorectal cancer genes, the penetrance for colorectal cancer is estimated to vary between 80 and $85 \%$ and between 40 and $60 \%$ for endometrial cancer. ${ }^{3}$ These are the ranges for average values. Additionally, the effectiveness of preventive interventions such as preventative surgery and early detection strategies, such as mammography, colonoscopy may be associated with a great deal of uncertainty. ${ }^{3,19}$

\section{Ways to communicate risks: the different kinds of communication strategies}

Risks can be presented through two types of messages. The first type uses a probability-based approach focusing on numerical information and the second focuses on the use of a contextualised approach informing a person about the antecedents and consequences of a health problem. ${ }^{20}$ These two approaches should be considered as complementary rather than independent.

\section{Probability-based approach}

When risk information is presented through probability information, there is a wide range of available formats ranging from numbers, verbal labels or visual displays. ${ }^{21-23}$ Numerical risks can be presented as absolute numbers or as relative risks, odds ratios or ratios. They can be expressed as frequencies of events, proportions, percentages or probabilities. Since some people experience difficulties in dealing with numbers, verbal descriptions of the risk magnitude, that is, 'an unlikely event', 'a risk higher than average', 'a higher risk than another woman of the general population' can also be used. However, translating numerical probability expressions into its verbal equivalents and vice versa is a complex problem. ${ }^{24}$ Risk information can be given for different cumulated periods of time or for a specified time period. Visual displays (or graphics) can aid risk presentation. They have at least three desirable properties for communicating risk: they reveal data patterns that may otherwise go undetected (line graphs for conveying trends in data; pie charts and bar graphs for proportions); some graphic displays can generate additional information, such as comparative risks. Another appealing aspect of graphical presentation is the clarity of the visual display of risk information. Graphics may also be useful for communicating uncertainty around risk estimates. $^{22}$

\section{Contextualised approach}

In the light of the limitations of a probability-based approach to communicate risk information, an alternative method provides people with information to assist them in understanding the personal implications of a given health risk. Information about the magnitude of risk is often viewed as insufficient since counsellees are interested to know what causes a health problem, the severity of its consequences and what can be done to either prevent it or treat it. ${ }^{20}$ This informational context will help people to understand and interpret their risk. A variety of methods can be considered contextual. Some have emphasised information about the aetiology of a disease, that is, its antecedents and the relevant risk factors. For example, the fact that having a mother and a sister with breast cancer may be used: this provides people with specific information regarding the link between a health problem and their own family history. It is considered to contextualise the risk and to help the patient understand his/her own situation. People who easily bring a risk to mind (for example through personal experience of the condition) may infer a greater personal risk than people who do not. ${ }^{20}$ Another way to contextualise the risk communication process is to make the consequences of the risk more salient to the recipient. This could be done through testimonials from people who have experienced the health problem (in videos for example) or through the identification of a family member who has developed the disease. This way, the severity of the health problem, its consequences or the availability of preventive interventions can all be illustrated. However, increasing awareness of the severity or the deleterious consequences of a disease, without offering interventions for prevention or cure, 
may be psychologically deleterious and should be done with caution. ${ }^{8}$ While this may not apply to most cancer genetic consultations, since the majority of counsellees are 'close' to their affected relatives, a 'new' issue about personal risk should be raised carefully in hereditary breast/ovarian cancer because no ideal preventive solution is yet available. Cancer worries can be addressed using a contextualised approach; for example, using the advantages and disadvantages of screening behaviour (eg, the accessibility of mammography screening, and the embarrassment surrounding colonoscopy) can help focus discussion of a risk management strategy taking account of the patients' views and concerns. Information and advice can be included to facilitate the individual's way of coping with an increased genetic risk.

\section{Complementary instruments to the probability-based} and to the contextualised approaches

Two complementary methods of risk presentation can be distinguished. They can complement both probability and contextualised approaches. The first refers to tailored communication and the second refers to information aids that complement the providers' message without tailoring precisely on the patients' characteristics.

Message tailoring is a process found in social marketing. ${ }^{25}$ Tailored communication refers to the adaptation of information that best fits the relevant needs and characteristics of the patient. It uses materials created especially for an individual, based on information about that person and providing individually relevant and appropriate information even adapted to patient's own coping style. $^{4,16,26-28}$

The information can be provided in a variety of ways, such as providing a personalised letter summarising the consultation, ${ }^{27,29}$ audiotape material or computer-generated information. A growing number of software programs can be used to create tailored print communication. ${ }^{4}$ Over recent years, other tools have been introduced to help patients understand their risks through probabilistic and contextualised information complementary to the genetic counselling process: we distinguish here the development of leaflets, video and interactive media, and also the accessibility of telephone services that were described in the context of cancer care/prevention in general. ${ }^{30-35}$

In parallel, other kinds of complementary information tools have been tested such as decision aids, the objectives of which are not specifically focused on risk communication but on decision-making. ${ }^{33}$ 'Decision aids are interventions designed to help people make specific and deliberative choices among options (including status quo) by providing (at a minimum) information on the options and outcomes relevant to a person's health status' ${ }^{36}$ One of the main rationales for using decision aids such as leaflets, videos, etc. is to reduce 'inappropriate' practice variation. Since asymmetry of information available to practitioners and patients regarding options, outcomes and values is assumed to exist, choices may more appropriately reflect patients' preferences with the correction of decision aids.

\section{Effectiveness of communication strategies}

The effectiveness of risk communication strategies clearly depends on the criteria used to assess the effectiveness of the process and consequently on the initial objectives of risk communication. In the introduction to this paper, two major objectives were specified: change or modification of health care behaviour and the facilitation of informed decision making. ${ }^{9-11}$ The latter objective is more relevant to the use of decision aids. ${ }^{33}$

The majority of studies assessing the effectiveness of risk communication have focused on the change in health care behaviour or in risk perception, a 'proxy' variable. However, there is insufficient empirical evidence from longitudinal studies that altering risk perception will motivate precautionary health behaviour. ${ }^{37}$ Studying the relationship between risk perception and health behaviour raises major methodological problems ${ }^{37}$ because there is an underlying association between perceived vulnerability and health behaviour and because people who have a particular behaviour interpret their risk according to that behaviour.

\section{Probability-based approach}

Studies assessing the effectiveness of the probability-based approach have tried to determine how different presentation formats affect people's ability to 'understand' the information provided concerning the risk magnitude. Many studies show that people cannot reliably understand numerical probability statistics and their interpretation is dependent on their level of numeracy and on the specific numbers used to illustrate a risk. The precision afforded by a numerical probability estimate may be appealing for providers and counselees, ${ }^{38,39}$ but its influence on lay people's beliefs and behaviour is anything but precise. ${ }^{10,20,39}$ When provided with numerical estimates, people often transform the probability value into discrete categories (high or low risk) and consistent with this result, behavioural intentions are more related to verbal labels than to numerical probability estimates. ${ }^{20,26}$ People also need comparisons between the probability of different risks to be able to interpret absolute risk information. This requires the concept of relative risk, often presented by the odds ratio, although these descriptors may be difficult to explain. ${ }^{20,26}$

It has been argued that giving risk estimates as percentages - rather than relative risks or in qualitative terms - leads to better understanding, and that short-term age-related estimates may be of more value than cumulative lifetime risks. ${ }^{26} \mathrm{~A}$ recent study of numerical risk 
information showed that the presentation of event frequency (eg, in over 100 women of the general population, 10 are likely to develop cancer in their lifetime) was better than the presentation of the equivalent probabilities (ie, for a woman of the general population, the probability of developing cancer in her lifetime is 0.10). ${ }^{40}$ The use of verbal labels may be preferred to numbers alone, ${ }^{10}$ but in a recent randomised trial, the two methods of presentation were found to be equivalent. ${ }^{41}$ However, whatever the difficulties, communicating quantitative information is a matter of necessity as this knowledge is a necessary basis for effective decision-making. ${ }^{42}$ In two of the few surveys investigating patients' preferences towards cancer risk communication, the majority of the British women interviewed in the cancer genetic clinic ${ }^{38}$ and $50 \%$ of the Australian women interviewed in a comparable setting ${ }^{39}$ expressed their preferences for quantitative risk information.

The presentation of individual risk estimates is more likely to change behaviour than the presentation of overall population estimates ${ }^{43}$ and those risks covering a shortterm period were more effective than cumulative risks. ${ }^{44}$

Visual displays have been evaluated primarily on the basis of their ability to affect people's perceptions of risk magnitude, relative risk and intentions to modify riskrelated behaviours. Some examples of visual displays that have been used to communicate risks are described in detail by Lipkus. ${ }^{22}$ These are (1) risk ladder, (2) stick, human and Chernoff faces, (3) line graph, (4) dots and X's in which the X's represent those affected by the hazard, (5) marbles, (6) pie chart and (7) histogram. Most of the preliminary experimental evidence suggests that combining visuals with numerical and written information improves the perceived helpfulness of the information and the accuracy of perceived risk. ${ }^{22}$ Visual displays are attractive for the presentation of uncertainty around a risk estimate, but as yet their effectiveness in this field has not been evaluated. Research is urgently needed to guide the presentation of uncertainty in the context of genetic risks. ${ }^{45}$ Discussing uncertainty has been shown for some people to be a sign of honesty greatly appreciated, whereas for others uncertainty represents a sign of incompetence. ${ }^{26}$ From the perspective of health care providers, there is the difficulty not only of interpreting the uncertainty of risk estimates, but also to judge the variability in their tolerance for uncertainty, depending on factors such as gender, age and medical speciality. ${ }^{46}$

The manner in which risk information is presented is but one of several influences on counsellees' interpretation of a given probability: people's risk estimates will reflect a broader set of beliefs influenced by knowledge, personality and personal aspirations. ${ }^{20}$

\section{Contextualised approaches}

The form of the risk communication message itself influences risk perception. 'Message framing' refers speci- fically to the effect of the positive (gain frame) or negative (loss frame) emphasis in a message on the consequences of adopting or failing to adopt a particular health care behaviour. Gain-framed messages usually present the benefits that are accrued through adopting the behaviour, that is, 'obtaining a preventative oophorectomy can prevent tumours of the ovary; this maximises your preventive options'. Loss-framed messages generally convey the costs of not adopting the requested behaviour, that is, 'in absence of preventative oophorectomy, tumours of the ovary cannot be prevented; this minimises your preventive options'. Although these two messages convey the same information, their effectiveness depends on the type of health behaviour being promoted. For mammography, it has been discovered that messages framed in term of losses (costs) motivated more behaviour change (adherence or screening) than gain-framed messages. ${ }^{25}$ For breast self-examination, or the use of sunscreens, loss messages also appeared to be more effective in changing behaviour than gain messages. ${ }^{25,47}$ The treatment options available remain the main determinant in behavioural change, $^{43}$ and the effectiveness of message framing depends on the type of health behaviour being promoted. ${ }^{25,48-50}$

\section{Complementary tools}

Tailored information appears effective for changing risk perception or screening behaviour, although some researchers consider that there is insufficient data to either support or refute the hypothesis. ${ }^{26,37,51}$ It seems necessary to adapt the information to the cognitive processing style of their recipients, and to take account of their readiness for behaviour change (cf Weinstein cited by Gerrard et al ${ }^{37}$ and Marteau et al $^{52}$ ). In behavioural models, the concept of self-efficacy has been shown to be related to subsequent behaviour. This concept describes the person's confidence in his/her ability to modify his/her behaviour. For example, you may know that because of your genetic predisposition to colorectal cancer you need to ask for a colonoscopy, but you may not feel able to ask for the test because you are not confident you could cope with the procedure or its consequences. Interest in the use of biostatistical models to tailor risk information also needs to be highlighted. ${ }^{37,53}$ These models use epidemiological data, or published statistical modelling to tailor individual risk information. For example, the Harvard Cancer Risk Index gives individual estimates of cancer risks and individualised recommendations for preventive actions concerning risk factors to which the individual is really exposed. The model has been shown to be related to intentions to change risk exposure or behaviour. ${ }^{53}$ Biostatistical models can also be used in the context of cancer genetic consultations.

Recently, patients' preferences for genetic counselling delivered by a counsellor or a CD-Rom have been studied. ${ }^{34}$ This study showed that patients preferred counsellors to 
address their concerns, discuss options or answer specific questions, whereas a CD-Rom was accepted or preferred because it was informative but could be used in privacy at the counsellee's own pace.

The effectiveness of decision aids can be measured through specific outcomes such as knowledge of options available, expectations, decisional conflict and active decision making of the participants. ${ }^{36}$ In this review, only one study of a decision aid intervention was found in the context of cancer genetics. ${ }^{36,54}$ In this study, no modification in risk perception or in decision-making for BRCA1 testing was shown as a result of the intervention. The before/after studies and randomised controlled trials are consistent in showing that decision aids have the greatest effect on the choices of those who are undecided at baseline but are less likely to change the decisions of the individuals who have a stated preference at baseline. ${ }^{33}$

\section{Discussion}

There are several major limitations to consider when comparing studies trying to demonstrate the effects of risk communication. The first arises from the heterogeneity of the assessments of risk perception/behavioural changes, the second from the heterogeneity of the risk communication strategies used and the third from the difficulty of conducting experimental studies in the clinical setting. ${ }^{55}$ Therefore, it is very difficult to tease out the effects of mixed communication strategies normally used in clinical practice. ${ }^{56-58}$ In a meta-analysis, Meiser ${ }^{57}$ showed that risk perception accuracy increased after breast/ovarian cancer genetic counselling, but since no data were reported about the communication strategy used in the reviewed studies, it is difficult to know whether some processes are more effective than others. Communication of risks also depends upon social context, environment and individual differences of the health care professionals. ${ }^{25,59}$ Since most studies have been carried out in North America or in the UK, the generalisability of these results to other cultural settings and to different health care organisations has to be studied further. ${ }^{58}$

However, even if there is no overall consensus on the effectiveness of risk communication strategies, there appears to be an agreement on the following principles. A 'multi-step process' of risk communication in cancer genetics could underpin these principles.

Step 1: Assess the a priori beliefs, knowledge, preferences, expectations, anxiety and coping styles of the recipients before deciding how to communicate risk information. This information will then be helpful as baseline to tailor the risk communication process.

Step 2: Select and prioritise the information to be given to the counsellee: decide on the risks to be presented, their magnitude, their uncertainty and their formats being employed.
The specific cancer risk may be put in perspective with other risks (other cancers, other diseases). The management options and their associated risks may be discussed.

Many people have difficulty in understanding quantitative information, and the effectiveness of interventions relying solely on numerical probability has been limited. Greater success is expected for communication strategies that give people with a broader information base using several presentation formats (absolute and relative risks).

Step 3: Provision of feedback from the consultation to the counsellee appears to be welcome. Interest in standardised tools that complement the consultation has been highlighted (leaflets, videos, CD-Rom) as they give the counsellee the opportunity to acquire information in privacy and at his/her own pace. Tailored print communication through a personal letter summarising the consultation for the counsellee is also suggested. The possibility of having several consultations should be considered in order to deliver information about the different risks step by step.

\section{Conclusion}

Cancer genetic counselling services have emerged from a growing scientific field. They provide some hope to the counsellees, entangled in a very complicated message which includes uncertainty, difficult questions about disease development for the individual, close family members and offspring. Yet the message can be severe and threatening, even potentially harmful. The counsellor's role is extremely difficult: namely to deliver, in each encounter, all the relevant information while taking into consideration specific characteristics and needs of the client. In other words, every session has to be professionally conducted, transmitting 'standard' information on the one hand, and at the same time - unique in its adaptation to the individual - taking into consideration attitudes, concerns, preferences, while using the most effective strategies.

It is very important to provide objective risk information to the target population, but it should be borne in mind that this population includes not only those choosing to receive genetic counselling, but others who are less enthusiastic about this service. There are individuals who refuse to attend altogether, as well as those who attend after a lot of deliberation, still hesitating as they participate in the session. Risk communication, as part of the process of genetic counselling, can be best provided with awareness of the difficult situation the counsellees are in, with acceptance of their personal preferences and concerns, and, mainly, the tailoring of the scientificprofessional message to the receivers' ability and willingness to cope. 


\section{Acknowledgements}

This research has been supported by the European Community, FP5, Contract QLG7-CT-2001-30236.

\section{References}

1 Kessler S: Psyche and helix: psychological aspects of genetic counseling. New York: Wiley, 2000

2 Armstrong K, Eisen A, Weber B: Assessing the risk of breast cancer. $N$ Engl J Med 2000; 342: 564-571.

3 Emery J, Lucassen A, Murphy M: Common hereditary cancers and implications for primary care. Lancet 2001; 358: 56-63.

4 Rimer BK, Glassman B: Is there a use for tailored print communications in cancer risk communications? J Natl Cancer Inst Monogr 1999; 25: 140-148.

5 Edwards A, Elwyn G, Mulley A: Explaining risks: turning numerical data into meaningful pictures. BMJ 2002; 324: $827-830$.

6 Vlek C: Risk assessment, risk perception and decision making about courses of action involving genetic risks. Birth Defects Orig Articles Ser 1987; 23: 171-207.

7 Decruyenaere M, Evers-Kiebooms G, Welkenhuysen M, Denayer L, Claes E: Cognitive representations of breast cancer, emotional distress and preventive health behaviour: a theoretical perspective. Psycho-oncology 2000; 9: 528-536.

8 Kreuter MW: Dealing with competing and conflicting risks in cancer communication. J Natl Cancer Inst Monogr 1999; 25: 27-35.

9 Maibach E: Cancer risk communication - what we need to learn. J Natl Cancer Inst Monogr 1999; 25: 179-181.

10 Weinstein ND: What does it mean to understand a risk? Evaluating risk comprehension. J Natl Cancer Inst Monogr 1999; $15-20$.

11 Raffle AE: Information about screening - is it to achieve high uptake or to ensure informed choice? Health Expect 2001; 4: 92-98.

12 de Jong MM, Nolte IM, te Meerman GJ et al: Genes other than BRCA1 and BRCA2 involved in breast cancer susceptibility. J Med Genet 2002; 39: 225-242.

13 Burke W, Press N, Pinsky L: BRCA1 and BRCA2: a small part of the puzzle. J Natl Cancer Inst 1999; 91: 904-905.

14 Phillips KA, Glendon G, Knight JA: Putting the risk of breast cancer in perspective. $N$ Engl J Med 1999; 340: 141-144.

15 Emmons K, Kalkbrenner K, Klar N, Light T, Schneider K, Garber J: Behavioral risk factors among women presenting for genetic testing. Cancer Epidemiol Biomark Prevent 2000; 9: 89-94.

16 Schwartz LM, Woloshin S, Welch HG: Risk communication in clinical practice: putting cancer in context. $J$ Natl Cancer Inst Monogr 1999; 124-133.

17 Struewing JP, Hartge P, Wacholder S et al: The risk of cancer associated with specific mutations or BRCA1 and BRCA2 among Ashkenazi Jews. N Engl J Med 1997; 336: 1401-1407.

18 Ford D, Easton DF, Stratton $\mathrm{M}$ et al: Genetic heterogeneity and penetrance analysis of the BRCA1 and BRCA2 genes in breast cancer families. Am J Hum Genet 1998; 62: 676-689.

19 Eisinger F, Alby N, Bremond A et al: Recommendations for medical management of hereditary breast and ovarian cancer: The French National Ad Hoc Committee. Ann Oncol 1998; 9: 939-950.

20 Rothman AJ, Kiviniemi MT: Treating people with information: an analysis and review of approaches to communicating health risk information. J Natl Cancer Inst Monogr 1999; 44-51.

21 Lipkus IM, Crawford Y, Fenn K, Biradavolu M, Binder RA, Marcus A, Mason M: Testing different formats for communicating colorectal cancer risk. J Health Commun 1999; 4: 311-324.

22 Lipkus IM, Hollands JG: The visual communication of risk. J Natl Cancer Inst Monogr 1999; 25: 149-163.

23 Schapira M, Nattinger A, McHorney C: Frequency or probability? A qualitative study of risk communication formats used in health care. Med Decis Making 2001; 21: 459-467.
24 Kong A, Barnett GO, Mosteller F: How medical professionals evaluate expressions of probability. N Engl J Med 1986; 315: 740-744.

25 Salovey P: Persuasion for the purpose of cancer risk reduction: a discussion. J Natl Cancer Inst Monogr 1999; 25: 119-122.

26 Bottorff JL, Ratner PA, Johnson JL, Lovato CY, Joab AA: Communicating cancer risk information: the challenges of uncertainty. Patient Educ Counsel 1998; 33: 67-81.

27 Hallowell N, Murton F: The value of written summaries of genetic consultations. Patient Educ Couns 1998; 35: 27-34.

28 Wade WM: Women receiving genetic counseling for breast cancer risk: cancer worry, psychological distress, and risk recall accuracy. Disser Abstr Int 2001; 61: 3865.

29 Evans DGR, Blair V, Greenhalgh R, Hopwood P, Howell A: The impact of genetic counselling on risk perception in women with a family history of breast cancer. Br J Cancer 1994; 70: 934-938.

30 Cull A, Miller H, Portefield $\mathrm{T}$ et al: The use of videotaped information in cancer genetic counselling: a randomized evaluation study. Br J Cancer 1998; 77: 830-837.

31 Maibach EW, Davis SW, Ter Maat J, Rivera N: Promoting cancer prevention and screening: the impact of the Cancer Information Service. Part 7. J Health Commun 1998; 3: 97-108.

32 Strecher VJ, Greenwood T, Wang C, Dumont D: Interactive multimedia and risk communication. J Natl Cancer Inst Monogr 1999; $134-139$.

33 O'Connor AM, Fiset V, DeGrasse C et al: Decision aids for patients considering options affecting cancer outcomes: evidence of efficacy and policy implications. J Natl Cancer Inst Monogr 1999; 67-80.

34 Green MJ, McInerney AM, Biesecker BB, Fost N: Education about genetic testing for breast cancer susceptibility: patient preferences for a computer program or genetic counselor. Am J Mved Genet 2001; 103: 24-31.

35 Green MJ, Biesecker BB, McInerney AM, Mauger D, Fost N: An interactive computer program can effectively educate patients about genetic testing for breast cancer susceptibility. Am J Med Genet 2001; 103: 16-23.

36 O'Connor AM, Stacey D, Rovner D et al: Decision aids for people facing health treatment or screening decisions. Cochrane Database Syst Rev 2001; 25: 140-148.

37 Gerrard M, Gibbons FX, Reis-Bergan M: The effect of risk communication on risk perceptions; the significance of individual differences. J Natl Cancer Inst Monogr 1999; 94-100.

38 Hallowell N, Statham H, Murton F, Green J, Richards M: 'Talking about chance': the presentation of risk information during genetic counseling for breast and ovarian cancer. I Genet Counsel 1997; 6: 269-286.

39 Lobb EA, Butow PN, Meiser B et al: Women's preferences and consultants' risk communication in familial breast cancer consultations: impact on patient outcomes. J Med Genet $2003 ; 25$.

40 Wilkniss S: Communication of cancer risk information in genetic counseling: does format of presentation affect understanding? Disser Abstr Int B 2000; 61: 3296.

41 Marteau TM, Saidi G, Goodburn S, Lawton J, Michie S, Bobrow M: Numbers or words? A randomized controlled trial of presenting screen negative results to pregnant women. Prenat Diagn 2000; 20: $714-718$.

42 Fischhoff, B: Why (cancer) risk communication can be hard. J Natl Cancer Inst Monogr 1999; 25: 7-13.

43 Edwards A, Hood K, Matthews E et al: The effectiveness of one-toone risk communication interventions in health care: a systematic review. Med Decis Making 2000; 20: 290-297.

44 Bryant H, Brasher P: Risks and probabilities of breast cancer: short-term versus lifetime probabilities. Can Med Assoc J 1994; 150: $211-216$.

45 Johnson B, Slovic P: Presenting uncertainty in health risk assessment: initial studies of its effects on risk perception and trust. Risk Anal 1995; 15: 485-494. 
46 Geller G, Tambor ES, Chase GA, Holtzman NA: Measuring physicians' tolerance for ambiguity and its relationship to their reported practices regarding genetic testing. Med Care 1993; 31: 989-1001.

47 Williams T, Clarke T, Borland R: Effects of message framing on breast cancer related beliefs and behaviors: the role of mediating factors. J Appl Soc Psychol 2001; 31 (Special issue): 925-950.

48 Slovic P, Fischoff P: Facts versus fears: understanding perceived risk. in Kahneman D, Slovic P, Tversky A (eds) Judgment under uncertainty: heuristics and biases. Cambridge: Cambridge University Press, 1982, pp 464-489.

49 Shiloh S, Sagi M: Effect of framing on the perception of genetic recurrence risks. Am J Med Genet 1989; 33: 130-135.

50 Jasper JD, Goel R, Einarson A, Gallo M, Koren G: Effects of framing on teratogenic risk perception in pregnant women. Lancet 2001; 358: 1237-1238.

51 Vernon SW: Risk perception and risk communication for cancer screening behaviors: a review. J Nat Cancer Inst Monogr 1999; 25: $101-109$.

52 Marteau T, Lerman C: Genetic risk and behavioral change. BMJ 2001; 322: 1056-1059.

53 Emmons KM, Koch-Weser S, Atwood K, Conboy L, Rudd R, Colditz G: A qualitative evaluation of the Harvard Cancer Risk Index. J Health Commun 1999; 4: 181-193.

54 Lerman C, Biesecker B, Benkendorf JL et al: Controlled trial of pretest education approaches to enhance informed decision- making for BRCA1 gene testing. I Natl Cancer Inst 1997; 89: $148-157$.

55 Brain K, Gray J, Norman P et al: Randomized trial of a specialist genetic assessment service for familial breast cancer. J Natl Cancer Inst 2000; 92: $1345-1351$

56 Woloshin S, Schwartz LM, Black WC, Welch HG: Women's perceptions of breast cancer risk: how you ask matters. Med Decis Making 1999; 19: 221-229.

57 Meiser B, Halliday J: What is the impact of genetic counselling in women at increased risk of developing hereditary breast cancer? A meta-analytic review. Soc Sci Med 2002; 54: 1463-1470.

58 Hopwood P: Breast cancer risk perception: what do we know and understand? Breast Cancer Res 2000; 2: 323-327.

59 Aspinwall LG: Introduction of section: persuasion for the purpose of cancer risk reduction: understanding responses to risk communications. J Natl Cancer Inst Monogr 1999; 25: 88-93.

60 Croyle RT, Lerman C: Risk communication in genetic testing for cancer susceptibility. I Natl Cancer Inst Monogr 1999; 25: $59-66$.

61 McBride C, Halabi S, Bepler G, Lyna P, McIntyre L, Lipkus I, Albright J: Maximizing the motivational impact of feedback of lung cancer susceptibility on smokers' desire to quit. $J$ Health Commun 2000; 5: 229-241.

62 Lipkus IM, Biradavolu M, Fenn K, Keller P, Rimer BK: Informing women about their breast cancer risks: truth and consequences. Health Commun 2001; 13: 205-226. 